\title{
Mengatasi Sibling Rivalry PadaAnak Bersama Orang Tua
}

\author{
Pratiwi Gasril*, Santoso, Juli Widiyanto, Yeni Yarnita, Isnaniar, \\ Maswarni, Wiwik Norlita \\ Fakultas MIPA dan Kesehatan, Universitas Muhammadiyah Riau \\ Email : pratiwi@umri.ac.id
}

\begin{abstract}
The quarrels that occur between children and their siblings are called Sibling Rivalry. If Sibling Rivalry is handled properly, it will become a stage to support children's development, socially and emotionally. This journal of community service aims to increase parents' knowledge of adjusting parenting styles to overcome Sibling Rivalry, especially the children at pre-school age. The method that used in using the questionnaire method. The variables are the parents, and the teachers. The result is, parents' mindset about dealing with sibling rivalry is in a good category and continues to increase.
\end{abstract}

Keywords: Sibling Rivalry, parents

\section{Abstrak}

Pertengkaran yang terjadi pada anak - anak dengan saudara mereka disebut Sibling Rivalry. Apabila Sibling Rivalry diatasi dengan baik akan menjadi sebuah tahap untuk mendukung perkembangan anak, secara sosial maupun emosional. Jurnal mengenai pengabdian ini bertujuan untuk meningkatkan pengetahuan orang tua terhadap penyesuaian pola asuh untuk mengatasi Sibling Rivalry, terutama pada anak - anak dalam usia pra sekolah. Adapun metode yang digunakan adalah dengan cara menggunakan metode kuisioner. Adapun sasarannya adalah orang tua, dan guru. Hasilnya, pola pikir orang tua dalam menghadapi Sibling Rivalry berada dalam kategori baik dan terus meningkat.

Kata Kunci: Sibling Rivalry, orang tua

\section{PENDAHULUAN}

Sebagaimana dinyatakan dalam undang - undang sistem pendidikan Nasional Nomor 20 Tahun 2003 Pasal 28, bahwa "pendidikan anak usia dini pada jalur pendidikan formal berbentuk Taman Kanak- Kanak (TK), Raudhatul Athfal, atau bentuk lain yang sederajat. Salah satu TK di Pekanbaru ialah TK Pembina. Di TK Pembina, terdapat banyak siswa yang juga mengalami Sibling Rivalry. Kepala TK Pembina, Ibu Nartianis, M.Pd mengatakan bahwa banyak keluhan dari orang tua siswa mengenai pertengkaran yang dilakukan oleh anak - anak mereka. Pertengkaran ini dapat berupa saling memukul atau berkelahi, dan saling berebut mainan. Orang tua siswa meminta kepada pihak sekolah untuk menasehati anak - anak mereka, yang mana seharusnya permasalahan ini dapat diatasi oleh orang tua si anak. Seperti yang telah diketahui bersama, bahwa keluarga merupakan pendidikan dasar bagi seorang anak.

Hubungan antara anak dan orang tua serta saudara kandung merupakan hubungan paling dasar sebelum memasuki dunia sosial yang lebih luas. Pada dasarnya, seseorang saudara kandung memiliki pengaruh kuat terhadap saudara kandung lainnya. Hubungan atau interaksi antara saudara kandung tidak semuanya 
berlangsung dengan baik (misalnya diskusi dan saling bercerita), namun ada yang tidak baik seperti konflik atau pertengkaran (misal perbedaan pendapat dan rasa iri).

Chaplin (2000: 463) mendefinisikan siblingrivalry sebagai suatu kompetisi antar saudara kandung, misalnya adik perempuan dengan kakak laki-laki, adik laki-laki dengan kakakperempuan, adik perempuan dengan kakak perempuan, dan antara adik laki-laki dengan kakak lakilaki. Pertengkaran yang terjadi pada anak - anak atau Sibling Rivalry merupakan salah satu tahap dalam perkembangan sosial dan emosional seorang anak. Pertengkaran akan menjadikan saudara kandung lebih mengenal dan memahami satu sama lainnya. Pertengkaran ini tergantung pada perbedaan usia anak, kepribadian anak, serta pola asuh orang tua. Salah satu faktor yang mempengaruhi pola asuh orang tua adalah lingkungan sosial ekonomi, lingkungan sosial dapat ditinjau dari pekerjaan sedangkan tingkat ekonomi seseorang dapat dilihat dari penghasilan ${ }^{[2]}$. Pola asuh yang tepat dari orang tua akan mampu mengatasi ataupun mengurangi Sibling Rilvalry pada anak - anak. Tujuan kegiatan dan rencana pemecahan masalah disajikan dalam bagian ini. Karena, pola asuh yang diberikan orang tua juga dapat menjadi pengaruh bagi munculnya Sibling Rivalry.

Orang tua adalah figur penting yang menemani anak selama masa perkembangannya, terutama seorang ibu. Sudah sewajarnya apabila seorang ibu lebih sering menemani buah hatinya pada anak usia prasekolah ${ }^{[2]}$. Salah satu contohnya ialah perbandingan yang dilakukan orang tua terhadap anaknya, dan pemberian perhatian yang lebih pada anak lainnya, sehingga sang anak merasa direndahkan dan memunculkan reaksi Sibling Rivalry. Sibling rivalry akan terlihat lagi ketika umur mereka 3-5 tahun dan berlanjut pada umur 8-12 tahun pada usia sekolah, sibling rivalry lebih sering terjadi pada anak yang berjenis kelamin yang sama, khususnya perempuan ${ }^{[3]}$. Dengan pemberitahuan dan pemahaman mengenai Sibling Rivalry, maka orang tua diharapkan dapat mengerti serta mengoptimalisasikan pengasuhan yang baik dalam mendidik anak - anaknya. Pemberitahuan dan pemahaman ini dapat dilakukan dengan berbagai cara, seperti pengadaan workshop atau seminar mengenai Sibling Rivalry, ataupun pelatihan khususnya kepada ibu mengenai pola asuh dalam mengatasi Sibling Rivalry. Bahkan Straus dalam Lefrancois ${ }^{[4]}$ melaporkan ketika anak perempuan mempunyai saudara laki-laki namun tidak memiliki saudara perempuan maka ia dapat mengambil peran nya. Banyak permasalahan yang timbul karena pola asuh yang kurang tepat misalnya memberikan perhatian yang lebih pada anak yang lain sehingga akan menimbulkan reaksi sibling rivalry ${ }^{[5]}$.

Apabila pengetahuan dan penanganan yang dilakukan oleh orang tua meningkat dan berjalan berkesesuaian, maka permasalahan atau konflik antara anak satu dengan lainnya dapat berkurang ${ }^{[6]}$. Dengan pola asuh yang tepat pula, sibling rivalry dapat diatasi dan bahkan dikurangi. Selain itu, peningkatan pengetahuan kepada guru mengenai Sibling Rivalry juga cukup penting, mengingat bahwa guru memiliki peran untuk mendidik siswa selain pendidikan yang telah diperoleh di keluarga siswanya.

\section{METODE PENGABDIAN}

Kegiatan pengabdian untuk meningkatkan pengetahuan terhadap Sibling Rivalry dilakukan dengan cara membaca literatur, wawancara langsung terhadap sumber (yaitu Kepala TK Pembina Pekanbaru), penelitian, serta terjun langsung ke lapangan untuk mengetahui variabel - variabel yang diteliti, variabel tersebut adalah anak usia pra sekolah, orang tua khususnya ibu, dan 
guru. Penulis juga menggunakan kuesioner dengan judul riset "Analisis Hubungan Pola Asuh Orang Tua terhadap Kejadin Sibling Rivalry pada Anak Usia Pra Sekolah".

Lebih lanjut, kegiatan pengabdian ini dilakukan dalam 4 tahap, di antaranya :

1. Tahap persiapan (melakukan konsolidasi, menentukan sasaran, menyusun materi dan susunan kegiatan, perlengkapan media, arahan pengisian kuisioner sebelum di lakukannya webinar dan persiapan alat lainnya, dan sebagainya).

2. Tahap pelaksanaan.

Pada tahapan pelaksanaan ketua mengkoordinir jalannya kegiatan dari awal hingga akhir kegiatan, sedangkan anggota pengusul membantu ketua untuk mengatur jalannya kegiatan agar kegiatan pelatihan berjalan dengan lancar dan sesuai dengan tujuan.

3. Tahap evaluasi (kuesioner evaluasi materi yang telah disampaikan untuk mengetahui tingkat pemahaman peserta).

4. Tahap

pelaporan

(pertanggungjawaban kegiatan).

Ketua pengusul dan anggota pengusul bersama sama membuat laporan pertanggungjawaban kegiatan . kemudian melakukan publikasi ilmiah pada jurnal pengabdian Padamu Negeri UMRI, mempublikasikan pada media cetak Tribun dan media Online, serta menggunggah video kegiatan pengabdian

\section{HASIL DAN PEMBAHASAN}

Kegiatan pengabdian masyarakat ini di awali dengan tahap persiapan. Tim pengabdian masyarakat melakukan persiapan alat, bahan, dan semua yang diperlukan untuk kegiatan PKM, kemudian selanjutnya melakukan koordinasi dengan kepala sekolah TK Negeri Pembina 3 Pekanbaru terkait dengan kegiatan yang akan dilakukan. Setelah adanya koordinasi, maka diketahui jumlah peserta kegiatan dengan waktu pelaksanaannya.

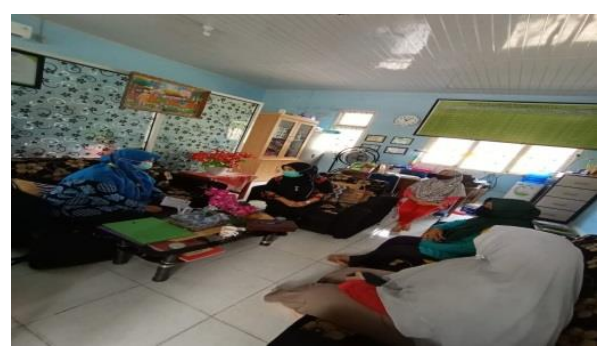

Gambar 1: koordinasi tim bersama pihak sekolah

Setelah dilakukan koordinasi, maka didapatkan sasaran dan waktu pelaksanaan pengabdian melalui webinar. Pelaksanaan webinar mengenai Sibling Rivalry sebagai fokus utama diselenggarakan pada 06 November 2020 secara online melalui aplikasi Zoom Meeting. Webinar yang dihadiri oleh 35 orang peserta dilangsungkan dengan metode ceramah yang kemudian dilanjutkan dengan tanyajawab.

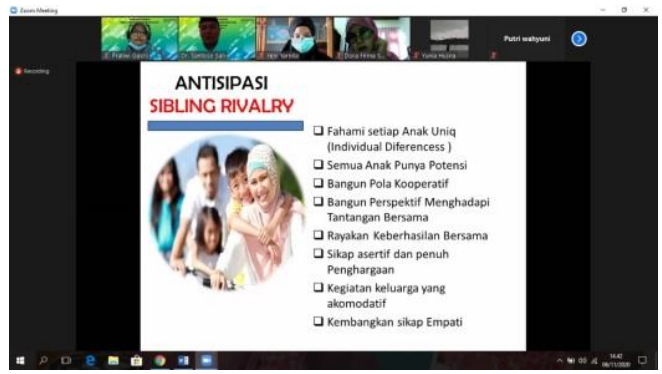

Gambar 2 : sosialisasi mengenai Sibling Rivalry

Pada penyelenggaraan webinar yang dilakukan, terdapat hasil - hasil yang telah dicapai, yaitu :

1. Tercapainya target peserta sosialisasi, yakni 35 orang. Namun, lembar evaluasi hanya diisi oleh 27 orang.

2. Tercapainya tujuan kegiatan sosialisasi, yakni meningkatnya pengetahuan, pemahaman, serta wawasan orang tua terkait pola asuh, Sibling Rivalry, cara menghadapi anak - anak yang 
mengalami Sibling Rivalry dengan kategori baik sebanyak $77 \%$. Hal ini dapat dilihat melalui hasil kuisioner sebelum dilakukannya webinar dengan tingkat pengetahuan peserta mengenai Sibling Rivalry dalam kategori rendah sebesar $65 \%$.

\section{SIMPULAN}

Ketika kegiatan webinar dilangsungkan, para peserta yang merupakan orang tua dan tenaga pendidik sangat aktif. Hal ini terbukti pada peningkatan pengetahuan yang tampak, dengan perbandingan lembar kuesioner sebelum webinar dengan lembar kuesioner (evaluasi) setelah webinar. Pengetahuan peserta kegiatan (orang tua dan tenaga pendidik) mengenai Sibling Rivalry sebelum mengikuti webinar cukup mengkhawatirkan, di mana peserta memiliki pengetahuan dalam kategori baik sebesar 25\%, kategori cukup sebesar 30\%, dan kategori rendah sebesar $65 \%$.

Sedangkan, setelah dilakukan webinar, kualitas pengetahuan peserta mengalami peningkatan, dan disimpulkan bahwa peserta berkategori baik sebanyak $77 \%$, kategori cukup sebanyak 13\%, dan kategori rendah sebanyak $10 \%$. Maka dari itu, dapat dikatakan bahwa pelaksanaan kegiatan ini berlangsung dengan lancar dan mencapai target dengan adanya peserta yang mampu memahami materi dengan baik. Kegiatan edukasi yang dilakukan memberi peningkatan pemahaman orang tua terhadap kasus sibling rivalry pada anak.

\section{UCAPAN TERIMAKASIH}

Kegiatan Pengabdian Kepada Masyarakat ini dapat terlaksana berkat dukungan dari berbagai pihak yang telah membantu secara material dan moril sehingga kegiatan pengabdian ini dapat terlaksana dengan baik. Oleh karena itu dalam kesempatan kali ini penulis menyampakaikan ucapan terimakasih kepada Rektor UMRI, LPPM UMRI, Dekan Fakultas MIPA dan Kesehatan, Ketua Program Studi Keperawatan dan Kepala Sekolah sekaligus majelis guru TK Negeri Pembina 3 Kota Pekanbaru.

\section{DAFTAR PUSTAKA}

[1.] Lefrancois,G.R.1986.Of Children An Introduction to Child Development $5^{\text {th }}$ Edition.California:Wedsworth Publishing Company

[2.] Chaplin, J.K. 2000. Kamus Lengkap Psikologi. Jakarta: PT Raja Grafindo Persada

[3.] Kewa, N., Sudiwati, N. L. P. W \& Ardiyani, V. M (2017) Hubungan pola asuh orang tua dengan reaksi sibling rivalry pada anak usia 3-4 tahun di Kelurahan Tlogomas, Kecamatan Lowokwaru, Kota Malang.

[4.] Bakri, F (2013). Gambaran pola asuh orang tua tentang kejadian kriminal pada remaja di lembaga pemasyarakatan kelas i Makassar. Skripsi. Universitas Islam Negeri Alauddin Makassar

[5.] Agustin, N (2013) Hubungan pola asuh dominan orang tua dengan sibling rivalry anak usia pra sekolah. Universitas Muhammadiyah Ponorogo

[6.] Armanda, S (2017)Hubungan peran ibu dengan kejadian sibling rivalry pada anak usia 3-5 tahun. Jombang. Diakses: Diakses tanggal 29 Juni $2019 . \quad$ http://repo.stikesicmejbg.ac.id.

[7.] Lefrancois,G.R.1986.Of Children An Introduction to Child Development $\quad 5^{\text {th }}$ Edition.California:Wedsworth Publishing Company 
[8.] Chaplin, J.K. 2000. Kamus Lengkap Psikologi. Jakarta: PT Raja Grafindo Persada 